\title{
A tüszőfolyadék biomarkereinek vizsgálata in vitro fertilizációs kezelésben részesült betegekben
}

\author{
Bódis József dr. ${ }^{1}$ - Sulyok Endre dr. ${ }^{2}$ - Várnagy Ákos dr. ${ }^{1}$ \\ Koppán Miklós dr. ${ }^{1}$ - Kovács L. Gábor dr. ${ }^{3}$ \\ ${ }^{1}$ Pécsi Tudományegyetem, Általános Orvostudományi Kar, Szülészeti és Nőgyógyászati Klinika, \\ Humán Reprodukciós Kutatócsoport, Pécs \\ ${ }_{2}^{2}$ Pécsi Tudományegyetem, Egészségtudományi Kar, Egészségtudományi Doktori Iskola, Pécs \\ ${ }^{3}$ Pécsi Tudományegyetem, Általános Orvostudományi Kar, Szentágothai János Kutatóközpont, \\ Humán Reprodukciós Kutatócsoport, Pécs
}

\begin{abstract}
A szerzók ismertetik vizsgálataik eredményeit, melyeket a közelmúltban az in vitro fertilizációs kezelésben részesülő betegeikben a tüszőfolyadék biomarkereinek analízisével értek el. A vizsgálatok célja annak feltárása volt, hogy az in vitro fertilizációs eljárás során a petesejtek aspirációjakor nyert tüszőfolyadék-biomarkerek lokális/ovarialis vagy szisztémás eredetúek, és milyen összefüggést mutatnak az in vitro fertilizáció eredményességét jelző paraméterekkel. Megerősítettük, hogy az autokrin/parakrin szerotoninrendszer már a fejlődés legkorábbi időszakában is múködőképes, és mind az anyai szérum, mind a tüszőfolyadék szerotoninszintje szignifikáns pozitív összefüggést mutatott az érett petesejtek számával és a klinikai terhességgel $(\beta=0,447, p=0,015$, illetve $\beta=0,443, p=0,016)$. Az agyi eredetû neurotrofikus faktor (BDNF) esetében ilyen kapcsolat nem volt igazolható, de a tüszőfolyadék BDNF- és szerotoninszintjei közötti pozitív korreláció $(r=0,377, \mathrm{p}=0,040)$ azt mutatja, hogy a két neurohormon 'feed-forward' (előrecsatoló ) szabályozása ovarialis szinten is múködik. A hypothalamicus kisspeptin esetében csupán a posztstimulációs anyai szérumhormonszint befolyásolta az érett petesejtek számát $(\beta=0,398, p=0,029)$. A triptofán-kinureninszerotonin rendszer elemzése azt mutatta, hogy kedvezőbb in vitro fertilizációs kimenetel várható, ha a szerotoninkinurenin egyensúly a szerotonin javára tolódik el. Az oxidatívstressz-markerek közül vizsgálták a DNS-károsodás biomarkerét, a 8-hidroxi-2'-deoxiguanozin és a totális antioxidáns-kapacitás szérum- és tüszőfolyadékszintjeit, és megállapították, hogy mindkét marker kedvezőtlenül befolyásolja az életképes embriók számát $(\mathrm{r}=0,302, \mathrm{p}=0,027$ és $\mathrm{r}=0,268, \mathrm{p}=0,039)$. A protektív hatású szirtuinok - nikotinamid-adenin-dinukleotid-függő hiszton-deacetiláz fehérjék - közül a vizsgált szirtuin-1 és szirtuin-6 a szérumszintektől függetlenül kimutatható a tüszőfolyadékban. Szignifikáns pozitív korreláció van a tüszőfolyadék-szirtuin-6 és az érettpetesejt-szám $(\mathrm{F}=6,609, \mathrm{p}=0,016)$, valamint a szérum-szirtuin-1 ( $\mathrm{F}=10,008, \mathrm{p}=0,005)$ és a szérum-szirtuin-6 $(\mathrm{F}=5,268, \mathrm{p}=0,031)$ és a klinikai terhesség gyakorisága között. Eredményeink alapján megállapítható, hogy a tüszőfolyadék biomarkereinek vizsgálata javíthatja az in vitro fertilizáció kimenetelének megítélését.
\end{abstract}

Orv Hetil. 2021; 162(14): 523-529.

Kulcsszavak: in vitro fertilizáció, tüszőfolyadék, biomarkerek

\section{Investigations of follicular fluid biomarkers in patients undergoing in vitro fertilization}

This article outlines the result of recent studies on several follicular fluid biomarkers in patients undergoing in vitro fertilization. The aim of these studies was to investigate whether 1) the follicular fluid biomarkers in question are produced locally by the ovaries or they originate from the circulating plasma, 2) and to establish their association with parameters of in vitro fertilization outcome. It was confirmed that the autocrine/paracrine serotonin system is functional already at the earliest stage of development and both maternal serum and follicular fluid serotonin levels were positively related to the number of mature oocytes $(\beta=0.447, p=0.015$ and $\beta=0.443, p=0.016$, respectively) and clinical pregnancy $(\beta=1.028, p=0.047)$. Such associations for brain-derived neurotrophic factor (BDNF) could not be found, but BDNF and serotonin in the follicular fluid were closely related $(r=0.377, p<0.040)$ suggesting that the feed-forward regulation of these neurohormones is activated at ovarian level. The hypothalamic kisspeptin in the 
post-stimulation maternal serum also increased the number of mature oocytes $(\beta=0.398, p=0.029)$. Analysis of the tryptophan-kynurenine-serotonin system showed a more favourable in vitro fertilization outcome when the serotonin-kynurenine balance was shifted and serotonin predominated over kynurenine. The oxidative stress markers, 8-hydroxy-2'-deoxyguanosine, an indicator of DNA damage and the total antioxidant capacity in follicular fluid and maternal serum had negative impact on the number of viable embryos $(\mathrm{r}=0.302, \mathrm{p}=0.027$ and $\mathrm{r}=0.268, \mathrm{p}=$ 0.039 ), respectively. The protective sirtuins - the nicotinamide adenine dinucleotide-dependent histone deacetylase proteins - could be detected in follicular fluid irrespective of their maternal serum levels. Significant positive relationship was demonstrated between follicular fluid sirtuin 6 and mature oocytes $(\mathrm{F}=6.609, \mathrm{p}=0.016)$ as well as between serum sirtuin $\mathrm{l}(\mathrm{F}=10.008, \mathrm{p}=0.005)$ and serum sirtuin $6(\mathrm{~F}=5.268, \mathrm{p}=0.031)$ and the rate of clinical pregnancy, respectively. On the basis of these results, it can be concluded that measuring several follicular fluid biomarkers may improve the prediction of the outcome of in vitro fertilization .

Keywords: in vitro fertilization, follicular fluid, biomarkers

Bódis J, Sulyok E, Várnagy Á, Koppán M, Kovács LG. [Investigations of follicular fluid biomarkers in patients undergoing in vitro fertilization]. Orv Hetil. 2021; 162(14): 523-529.

(Beérkezett: 2020. szeptember 21.; elfogadva: 2020. október 16.)

\section{Rövidítések}

5-HT $=5$-hidroxitriptamin; 8-OHdG $=8$-hidroxi-2'-deoxiguanozin; $\mathrm{BDNF}=$ (brain-derived neurotrophic factor $)$ agyi eredetû́ neurotrofikus faktor; DNS = dezoxiribonukleinsav; EFOP = Emberi Erőforrás Fejlesztési Operatív Program; ELISA = (enzyme-linked immunosorbent assay) enzimhez kapcsolt immunszorbens-vizsgálat; FSH = folliculusstimuláló hormon; $\mathrm{GnRH}=$ (gonadotropin-releasing hormone) gonadotropinfelszabadító hormon; hCG = humán choriogonadotropin; HPLC-MS-MS = (high-performance liquid chromatographytandem mass spectrometry) nagy hatékonyságú folyadékkromatográfia-tandem tömegspektrometria; IDO = indolamin2-3-dioxigenáz; IVF = in vitro fertilizáció; $\mathrm{LH}=$ luteinizáló hormon; NAD = nikotinamid-adenin-dinukleotid; ROS $=($ re active oxygen species) reaktívoxigén-származék; SIRT $=$ szirtuin; SSRI = (selective serotonin reuptake inhibitor) szelektív szerotoninvisszavétel-gátló; TAC = totális antioxidáns-kapacitás; $\mathrm{TDO}=$ triptofán-2-3-dioxigenáz; TrkB = tirozin-kináz-B; VEKOP = Versenyképes Közép-Magyarország Operatív Program

Az in vitro fertilizációs (IVF-) eljárás az elmúlt négy évtizedben az orvostudomány, a nőgyógyászat rutineljárásává vált. 1978-ban megszületett az első „lombikbébi”, akit azóta már több mint 5 millió követett, és az asszisztált reprodukciós módszerek új távlatokat nyitottak azon gyermektelen párok számára, akik kezelésére korábban nem volt lehetôség. Magyarországon az összes, meddőségi problémával küzdő házaspár száma eléri a populáció 15\%-át. Közülük természetesen nem mindenki számára indokolt az IVF-kezelés, azonban a megszületett csecsemók 1,5-2\%-a ilyen kezelést követően fogan hazánkban, és ez a szám folyamatosan emelkedik. Ez a körülmény az infertilitás és az IVF-eljárás kutatásának népegészségügyi jelentőségére hívja fel a figyelmet. Hazai szerzók a közelmúltban is közöltek fontos ismereteket a fertilizáció im- munológiai és inflammatorikus vonatkozásairól [1], valamint a fertilitást befolyásoló egyes tényezőkről [2].

A tüszőfolyadék (follicularis folyadék) a petesejtek közvetlen környezetét képezi, melynek összetétele meszszemenően befolyásolja a folliculusok fejlődését és a petesejtek érését. Részben az ovarialis granulosa- és thecasejtek, részben a petesejtek termelik, részben pedig a vér-follicularis barrieren átjutó transsudatum terméke. Olyan speciális közeget képez, mely biztosítja a petesejtek és a follicularis sejtek közötti kommunikációt, és hozzájárul a jó minőségú petesejt/embrió fejlődéséhez. Az IVF-eljárás során a petesejtek aspirációjakor rutinszerüen nyerhető, így alapul szolgálhat a fertilizáció sikerét és az IVF eredményességét jelző biomarkerek noninvazív vizsgálatához.

A klinikai gyakorlatban az egyes biomarkerek meghatározása mellett egyre inkább elterjedt a nagyszámú marker egyidejü vizsgálata. Ezek közül kiemelkedőek a fehérje (proteom)- és metabolit (metabolom)-profilok, valamint a génexpressziós mintázatok diagnosztikus és prediktív értékeinek meghatározására tett próbálkozások.

Munkacsoportunk az elmúlt években a tüszőfolyadék neurohormon- (szerotonin, 5-HT; kinurenin, kisspeptin, agyi eredetú neurotrofikus faktor $[\mathrm{BDNF}])$ tartalmának, oxidatívstressz-markereinek (8-hidroxi-2'-deoxiguanozin, 8-OHdG; totális antioxidáns-kapacitás, TAC) és egyes protektív faktorainak (szirtuin-1, szirtuin-6, rezveratrol) jelentőségét kívánta megismerni.

Vizsgálatainkat a már korábban is alkalmazott protokoll szerint végeztük: a kérdéses biomarkert az ovariumhiperstimuláció előtt, majd a tüszőfolyadék- és petesejtaspirációval egy idóben nyert anyai szérummintákban, valamint a tüszőfolyadékban határoztuk meg [3]. Ily módon lehetôvé vált a hiperstimuláció hatásának és az egyes markerek szisztémás vagy lokális/ovarialis eredetének megítélése, valamint az IVF eredményességét jelző 
paraméterekkel (az érett petesejtek és életképes embriók száma, kémiai és klinikai terhesség) külön-külön történő összevetése. Bár a tüszőfolyadék könnyen hozzáférhető az IVF-eljárás során, vizsgálatainknál a mintagyưjtés technikai és etikai okok miatt nem tüszőnként, illetve petesejtenként, hanem betegenként történt. A minta szelektív gyüjtése megoldható, de miután ez már eltér a rutin klinikai gyakorlattól, az ilyen mintavételt csupán kellő számú és eredményű hasonló vizsgálatból nyert kedvező tapasztalat után indokolt alkalmazni.

\section{A neurohormonok szerepének vizsgálata IVF-kezelt betegekben}

\section{Szerotonin $(5-H T)$}

Az 5-HT neurotranszmitter, mely fontos szerepet játszik a hypothalamus-hypophysis-gonad tengely múködésének szabályozásában és a női reprodukcióban: 5-HTaxon-végződéseket mutattak ki a hypothalamicus gonadotropinfelszabadító hormon (GnRH) neuronjaiban, és igazolták szabályozó szerepét a $G n R H$-gén expressziójában és a hormon szekréciójában, közvetve a hypophysealis FSH és LH szintézisében és szekréciójában; ezeken keresztül meghatározó tényezője az ovariumban zajló steroidogenesis, folliculogenesis és oogenesis centrális szabályozásának [4].

A központi szabályozás mellett kiemelt jelentőségú az 5-HT intraovarialis hatása. Ezt látszik alátámasztani, hogy 5-HT-t mutattak ki a tüszőfolyadékban, és az ovarialis granulosasejtekben az 5-HT közvetlenül is fokozta a progeszteron szekrécióját [5]. További jelentős felismerés, hogy az 5-HT-rendszer egyes elemeit (triptofánhidroxiláz, 5-HT, 5-HT-receptorok, 5-HT-transzporterek) mutatták ki petesejtekben és preimplantációs embriókban. Ezek a megfigyelések egyértelmúen arra utalnak, hogy az autokrin/parakrin 5-HT-rendszer már a fejlődés legkorábbi időszakában is múködőképes $[6,7]$. Az 5-HT jelentőségének vizsgálatát az is indokolta, hogy az IVF-kezelésben részesülő nők körében egyre gyakoribb a szelektív szerotoninvisszavétel-gátlók (SSRI-k) alkalmazása, melyek rontják az eljárás eredményességét, magzati károsodást, terhességi komplikációkat és az újszülöttek adaptációs zavarait okozhatják.

Vizsgálatainkat a Pécsi Tudományegyetem Szülészeti és Nőgyógyászati Klinikáján múködő Asszisztált Reprodukciós Központban 30 betegnél végeztük. A szuperovulációs kezelés, a fertilizáció módja és az embriószelekció az eddigi gyakorlatnak megfelelően történt. A szuperovulációs kezelés szuppressziós részét a GnRHagonista triptorelin adásával végeztük rövid, illetve hoszszú protokoll alkalmazásával. A stimuláció a betegre egyénileg szabott dózisú rekombináns FSH és LH adásával történt, a dózis 100 és 225 egység napi adása között mozgott a tüszőéréstől függően. A kezdő adagot a testtömegindex és a kor határozta meg.
Azon betegeknél, akik korábban kedvezőtlenül reagáltak a stimulációs kezelésre, a napi dózist maximum 300350 egységgel kezdtük, szükség esetén LH adásával kiegészítve. A tüszőérést a menstruációs ciklus 6. napjától másnaponta ultrahangvizsgálattal ellenőriztük. A tüszők méretétől függóen az alkalmazott gonodotropin menynyiségét egyénileg változtattuk. Amennyiben legalább két tüsző mérete elérte a 17 mm-t, $250 \mu \mathrm{g}$ hCG adásával ovulációindukciót végeztünk.

A hCG-adás után 36 órával rutin intravénás narkózisban ultrahangvezérelt transvaginalis folliculuspunkciót végeztünk; az embrió(k) beültetése 3-5 nappal a folliculuspunkció után történt. A petesejtek fertilizációja, majd a preembriók tenyésztése szekvenciális tápoldatban történt (Vitrolife, Göteborg, Svédország; G széria).

Az 5-HT-meghatározásokat ELISA-módszerrel (IBL International GmbH, Hamburg, Németország) végeztük.

Megállapítottuk, hogy az anyai szérum-5-HT az ovarium-hiperstimuláció hatására szignifikánsan emelkedett $(173,6 \pm 64,7$ vs. $238,0 \pm 107,1 \mathrm{ng} / \mathrm{ml}, \mathrm{p}<0,01)$, és a terhes csoportban jelentősen magasabb értékeket mértünk, mint a nem terhes csoportban $(\mathrm{p}<0,01)$ mind a hiperstimuláció előtt, mind azt követően. A tüszőfolyadékban az 5-HT alacsony koncentrációban volt jelen $(13,1 \pm 9,8 \mathrm{ng} / \mathrm{ml})$, és értéke függetlennek bizonyult mind az anyai szérumszintektől, mind az IVF kimenetelétől. Eredményeink többváltozós lineáris regressziós analízisével (Modell 1, $\mathrm{R}^{2}=0,336$ ) kimutattuk, hogy az érett petesejtek száma mint függő változó szignifikáns összefüggést mutatott a posztstimulációs anyai szérum$(\beta=0,447, p=0,015)$ és a tüszőfolyadék-5-HT-szintekkel $(\beta=0,443, p=0,016)$. Többváltozós logisztikus regressziós modell (Modell $3, \mathrm{R}^{2}=0,595$ ) alkalmazásával a klinikai terhesség mint függő változó ugyancsak szignifikáns kapcsolatban volt az anyai szérum-5-HT koncentrációjával $(\beta=1,028, \mathrm{p}=0,047)$.

Vizsgálataink megerősítették, hogy mind a keringő, mind a lokálisan képződő ovarialis 5-HT fontos tényező a női reproduktív funkció fenntartásában és az IVF eredményességének biztosításában [8].

\section{Agyi eredetü neurotrofikus faktor}

Mivel szoros kölcsönhatást írtak le az 5-HT és több hypothalamicus neuropeptid között, vizsgálatainkat kiterjesztettük a BDNF és a kisspeptin szerepének tisztázására. A BDNF elsődleges forrása a központi idegrendszer, de termelését perifériás szövetekben, köztük a vascularis endotheliumban, simaizomsejtekben és aktivált mononukleáris fehérvérsejtekben is kimutatták. Transzportjáért a thrombocyták felelősek, melyek aktiválásakor az 5-HT-vel együtt a plazmába kerül. A BDNF és receptora $(\operatorname{TrkB})$ az ovariumban is megtalálható, autokrin/parakrin múködésük alapvető feltétele a zavartalan folliculusképződésnek, a petesejt érésének, az implantációnak és a korai embrió és placenta fejlődésének [9]. 
IVF-kezelésben részesülő betegekben, cumulus- és granulosasejt-preparátumokban a BDNF-szekréció fokozását figyelték meg ösztradiol, hCG, LH és FSH hatására $[10,11]$.

Érdekes közlés, hogy az IVF-kezelés előtt nyert szérum-BDNF szignifikánsan alacsonyabb volt azokban az esetekben, melyekben a kezelés eredményes volt, és klinikai terhesség alakult ki, mint azokban az esetekben, melyekben a kezelés sikertelennek bizonyult [12].

Saját vizsgálatainkban, melyeket az 5-HT-vel együtt ELISA-módszerrel végeztünk (RayBiotech, Peachtree Corners, GA, USA), az ovarium-hiperstimuláció nem okozott változást a BDNF szintjeiben, és nem találtunk különbséget a terhes és a nem terhes csoport értékei között. Ugyanakkor a terhes csoport BDNF-tüszőfolyadékkoncentrációja szignifikánsan alacsonyabb volt, mint amit a nem terhes csoportban mértünk $(21,9 \pm 12,7$ vs. $47,6 \pm 5,9, \mathrm{p}<0,026)$. Ennek megfelelően szignifikáns negatív korrelációt igazoltunk a BDNF-szintek, valamint a petesejt- és embriószám, továbbá a kémiai és klinikai terhesség gyakorisága között. Alapvetően új megfigyelés, hogy szignifikáns pozitív korrelációt igazoltunk a tüszőfolyadék-BDNF és -5-HT között, ami arra utal, hogy a két hormon pozitív 'feed-back' (visszacsatoló) szabályozása ovarialis szinten is múködik, tehát a BDNF indirekt módon, az 5-HT-termelés stimulálása útján hozzájárulhat a reproduktív potenciál megőrzéséhez vagy javításához $[8]$.

\section{Kisspeptin}

A hypothalamicus peptidhormon, a kisspeptin a reprodukció egyik fontos pozitív szabályozója [13]. A hormont és receptorát az ovariumban is kimutatták, és meggyőző adatok bizonyítják, hogy fontos szerepet játszik a tüsző- és petesejtérésben, az embrió implantációjában és a placentációban [14]. Feltételezik, hogy az ovariumeredetű kisspeptin és a BDNF együttes hatásként növelik a petesejtek érését, múködő receptoraik hiányában a jelátviteli rendszer sérül, és korai petefészek-elégtelenség alakul ki [15]. Klinikai szempontból is jelentős felismerés, hogy az ovarium-hiperstimulációs szindróma miatt veszélyeztetett nőkben a kisspeptin-54 egyszeri vagy ismételt dózisban történő adásával kontrollált LH-kiáramlást és a petesejtek érésének javulását lehetett elérni [16].

Saját IVF-kezelt beteganyagunkban az ELISA-val mért kisspeptin (Peninsula Laboratories International, San Carlos, CA, USA) szérumkoncentrációját a hiperstimuláció szignifikánsan növelte $(0,50 \pm 0,18$ vs. $0,79 \pm$ $0,21 \mathrm{ng} / \mathrm{ml}, \mathrm{p}<0,01)$ de nem találtunk különbséget a terhes és a nem terhes csoport értékei között. A tüszőfolyadék kisspeptin-koncentrációja a többi vizsgált neurohormonhoz hasonlóan a szérumszintektől függetlennek bizonyult, alátámasztva annak ovarialis eredetét. Többváltozós lineáris regressziós modellt alkalmazva igazoltuk, hogy a posztstimulációs szérumkisspeptin az érett petesejtek számát pozitívan befolyásolta
$\left(\mathrm{R}^{2}=0,150, \beta=0,398, \mathrm{p}=0,29\right)$. Eredményeink és az irodalmi adatok alapján a megfelelően alkalmazott kisspeptinkezelés javíthatja az IVF eredményességét [8].

\section{Triptofán-kinurenin-szerotonin (5-HT)}

A triptofán esszenciális aminosav, melynek döntő többsége a fehérjeszintézisben hasznosul, a fennmaradó rész 95\%-a a kinureninúton katabolizálódik, és csupán $<5 \%$ szolgál 5-HT-prekurzorként. Az 5-HT és az IVF kapcsolatát az előző részben tekintettük át, az alábbiakban a kinurenin lehetséges szerepét elemezzük.

A triptofán-kinurenin konverziót két enzim mediálja: a májeredetú triptofán-2-3-dioxigenáz (TDO), melynek aktivitását a glükokortikoidok fokozzák, a progeszteron és az ösztrogének pedig gátolják. A másik enzim az indolamin-2-3-dioxigenáz, melyet citokinek és gyulladásos mediátorok aktiválnak, számos sejttípusban, köztük a monocytákban és makrofágokban is megtalálható [17]. A triptofánszint csökkenését a kinurenin és metabolitjainak növekedése és az 5-HT-szintézis csökkenése kíséri [18]. Mivel az 5-TH protektív reprodukciós hatását egyértelmúen igazolták, a triptofán-kinurenin út aktiválása az 5-HT következményes csökkenésével ronthatja a reprodukciós teljesítményt. Ennek ellentmondani látszik, hogy a TDO-t, IDO-t és a kinureninkatabolizmus további enzimjeit kimutatták a placentában, a deciduában és a korai embrióban, ahol immunológiai védelmet biztosít a sikeres implantációhoz és a zavartalan embrionális/fetalis fejlődéshez [19]. Ezen túlmenően számos vizsgálat arra is felhívta a figyelmet, hogy a triptofán-kinurenin rendszer egyes elemei az immuntolerancia kialakítása mellett fontos tényezők az oxidatív stressz elleni védelemben $[20,21]$. A kinureninek pozitív szerepét egyértelmúen az is bizonyítja, hogy az IDO enzim gátlása vagy a gén deletiója magzati veszteségeket és terhességi szövődményeket okozott [18].

Tekintettel arra, hogy mind a triptofán-kinurenin, mind a triptofán-5-HT rendszer protektív hatású, és mindkét metabolikus út verseng a szubsztrát triptofánért, optimálisnak az látszik, hogy egyik vonal sem dominál, hanem egyensúlyi helyzet alakul ki. Ennek ellenőrzésére a korábbi vizsgálati protokollt alkalmazva HPLC-MS-MS módszer felhasználásával 64 beteg azonos mintáiban meghatároztuk a triptofán, a kinurenin és az 5-HT szérum- és tüszőfolyadékszintjeit. Megállapítottuk, hogy az ovarium-hiperstimuláció hatására mindhárom metabolit koncentrációja csökkent, jelezvén, hogy kevesebb triptofán áll a két katabolikus út rendelkezésére. Az érett petesejtek száma a tüszőfolyadék-5-HTvel pozitív, míg a tüszőfolyadék triptofán/5-HT és kinurenin/5-HT arányokkal negatív korrelációt mutatott. Ennek megfelelően a terhes csoportban szignifikánsan magasabb szérum- $(\mathrm{p}=0,045)$ és tüszőfolyadék5 -HT $(\mathrm{p}=0,020)$, valamint alacsonyabb kinurenin /5-HT arányt $(\mathrm{p}=0,024)$ tudtunk igazolni. Többváltozós logisztikus regressziós analízissel az érett petesejtek számát 
mint függő változót csupán a tüszőfolyadék-5-HT befolyásolta szignifikánsan $(\beta=0,473, \mathrm{p}=0,001)$. Eredményeink azt igazolják, hogy kedvezőbb IVF-kimenetel várható, amennyiben az 5-HT-kinurenin egyensúly az 5-HT javára tolódik el [22].

\section{Oxidatívstressz-markerek és antioxidánsok vizsgálata IVF-kezelt betegekben}

\section{8-hidroxi-2'-deoxiguanozin (8-OHdG) és totális antioxidáns-kapacitás (TAC)}

A reaktívoxigén-molekulák (reaktívoxigén-származék, ROS; szuperoxid-anion, hidrogén-peroxid, hidroxilanion) a normális sejtanyagcsere termékei, és fontos szerepet játszanak a celluláris folyamatok szabályozásában. Abban az esetben azonban, ha túlzott termelésük meghaladja a sejtek antioxidáns-kapacitását, a ROS-ok reakcióba lépnek a sejtek fehérje-, lipid- és DNS-elemeivel, és celluláris diszfunkciót, morfológiai károsodást és apoptózist okozhatnak. IVF-kezelt betegekben fiziológiás ROS-képződés szükséges a petesejt egészséges éréséhez, a sikeres fertilizációhoz és az embrió zavartalan fejlődéséhez [23]. A tüszőfolyadék optimális ROS-szintje azonban nincs definiálva, és mind a túlzott, mind az elégtelen ROS-generálás kedvezőtlenül befolyásolja az IVF kimenetelét [24]. Ez a megfigyelés összhangban áll a „quiet metabolism" koncepciójával, mely szerint a normális metabolikus aktivitás felső vagy alsó határán túl az embrió életképessége csökken [25].

A közelmúlt kutatásai hívták fel a figyelmet az oxidatív DNS-károsodás részleges korrekciójának jelentőségére a női reprodukcióban. Megállapították, hogy a 8-OHdG mint az oxidatív DNS-károsodás biomarkere IVF-kezelt betegek granulosasejtjeiben és tüszőfolyadékjában negatívan korrelál a petesejtek és az embriók minőségével $[26,27]$.

A kérdés további tisztázására munkacsoportunk 61, IVF-kezelésben részesült beteg esetében meghatározta az anyai szérum és a tüszőfolyadék 8-OHdG-szintjét (ELISA; IBL International $\mathrm{GmbH}$ ) és totális nem enzimatikus antioxidáns-kapacitását (Trolox-kalibrált kemilumineszcenciás módszer). Megállapítottuk, hogy ovarium-hiperstimuláció hatására a szérum-TAC jelentősen növekedett $(95,4 \pm 17,8$ vs. $104,8 \pm 17,4 \mu \mathrm{mol} / 1, \mathrm{p}=$ 0,02), míg a 8-OHdG szignifikánsan csökkent (17,6 \pm $5,1$ vs. $15,6 \pm 5,3 \mathrm{ng} / \mathrm{ml}, \mathrm{p}<0,001)$. Mindkét biomarker kimutatható volt a tüszőfolyadékban, de lényegesen alacsonyabb koncentrációban, mint az anyai szérumban, és azzal nem mutatott összefüggést. A TAC és a 8-OHdG kapcsolatát vizsgálva azok tüszőfolyadék-értékei egymástól függetlennek bizonyultak, míg szérumkoncentrációjuk között szignifikáns negatív korrelációt észleltünk $(\mathrm{r}=-0,241, \mathrm{p}=0,009)$, jelezvén, hogy a magasabb TAC csökkenti a DNS-károsodást. További fontos megfigyelés, hogy mind a TAC $(\mathrm{r}=-0,302, \mathrm{p}=0,027)$, mind a
8-OHdG $(r=-0,268, p=0,039)$ kedvezőtlenül befolyásolja az embriók életképességét.

Eredményeink megerősítik azon törekvések szükségességét, melyek az IVF-eljárás során az oxidatív stressz csökkentésére irányulnak [28].

\section{Szirtuinok (SIRT1, SIRT6) és rezveratrol}

A SIRT-ek NAD-függő hiszton-deacetiláz enzim fehérjék, melyek bizonyos védelmet jelentenek az öregedéssel és az öregedéssel kapcsolatos kóros állapotokkal szemben. A proteincsalád 7 tagja ismert (SIRT1-7), melyek szövetspecificitása, szubcelluláris lokalizációja és aktivitása különböző. Általános jellemzőjük, hogy alapvető sejtfunkciók szabályozásában vesznek részt (energiaforgalom, redoxstatus, jelátvitel, sejtciklus, genomstabilitás) [29]. Az életkor előrehaladtával az ovariumfunkció is beszúkü̈l, a tüsző- és petesejtképzés csökken, a petesejtek minősége romlik. Az ovarium öregedésére jellemző változások szoros összefüggést mutatnak a nukleáris SIRT1 és SIRT6 szintjeivel [30]. SIRT1-hiányos egértörzsekben ovarium-diszfunkció alakul ki, és a petesejtek fejlődési potenciálja beszúkuul [31]. A közelmúltban végzett humánvizsgálatok is igazolták, hogy a SIRT1-7 tagjai a germinalis vesiculumokban és az érett petesejtekben jelen vannak, az érés folyamán up-regulációjuk következik be [32]. A SIRT-ek fertilitást javító hatásának közvetítésében az antioxidáns rezveratrol és a telomeráz aktivitásának növelése, a telomer integritásának védelme is szerepet játszik $[33,34]$.

Ezen irodalmi adatok alapján a korábban is alkalmazott vizsgálati protokoll szerint 30 , IVF-kezelt betegnél az anyai szérum- és a tüszőfolyadék-mintákban ELISAmódszerrel meghatároztuk a SIRT1- és SIRT6-, valamint a rezveratrolszinteket (Cloude-Clone Corporation, Houston, TX, USA). Megállapítottuk, hogy az ovariumhiperstimuláció hatására a szérum-SIRT1 a terhes csoportban szignifikánsan növekedett $(6,0 \pm 5,6$ vs. 7,9 \pm $3,4 \mathrm{ng} / \mathrm{ml}, \mathrm{p}<0,05)$, és jelentősen meghaladta a nem terhes csoport értékeit $(4,7 \pm 2,7 \mathrm{ng} / \mathrm{ml}, \mathrm{p}<0,05)$. A SIRT6 esetében ilyen változás nem következett be, de ezek értéke a terhes csoportban csökkent mind a hiperstimuláció előtt $(0,31 \pm 0,19$ vs. $0,14 \pm 0,07 \mathrm{ng} / \mathrm{ml}$, $\mathrm{p}<0,05)$, mind azt követően. Mindkét szirtuint (SIRT1, SIRT6) kimutattuk a tüszófolyadékban, de a szérumszintektől függetlennek bizonyultak, ami lokális, ovarialis termelésükre utal. Egyéb, ható tényezőkre történő korrekció után szignifikáns pozitív korrelációt találtunk a tüszőfolyadék-SIRT6 és az érettpetesejt-szám ( $\mathrm{F}=$ $6,609)$, valamint a szérum-SIRTl $(\mathrm{F}=10,008, \mathrm{p}=$ $0,005)$, szérum-SIRT6 ( $\mathrm{F}=5,268, \mathrm{p}=0,03)$ és a klinikai terhesség gyakorisága között. A rezveratrol sem a SIRT-ekkel, sem az IVF kimenetelét jelző markerekkel nem mutatott összefüggést.

Eredményeink megerősítették a SIRT-ek lehetséges szerepét a reprodukció sikerében, de további molekuláris 
biológiai vizsgálatok szükségesek a SIRT-enzimek aktivitásának meghatározására és esetleges epigenetikai változásainak feltárására [35].

\section{Következtetés}

Munkacsoportunk kiterjedten vizsgálta a tüszőfolyadék biomarkereit, és kísérletet tett az intraovarialisan képződő neurohormonok, oxidatívstressz-markerek és antioxidáns molekulák prediktív értékének meghatározására. $\mathrm{Az}$ intrafollicularis mikrokörnyezet ugyanis messzemenően befolyásolja a petesejtek érését, minőségét és a megtermékenyítésre való alkalmasságát. Optimális öszszetételének fenntartása feltétele a természetes és mesterséges megtermékenyítés sikerének, ezért minden genetikai vagy környezeti tényező, amely a granulosasejt-tüszőfolyadék egység funkcionális integritását és a tüszőfolyadék összetételét károsan befolyásolja, csökkenti a fertilizáció eredményességét. A biztató kezdeti eredmények ellenére szükségesnek tartjuk a vizsgálatok nagyobb beteganyagra történő kiterjesztését, diagnózisspecifikus csoportok képzését, valamint a potenciális markerek génexpressziós mintázatának és esetleges poszttranszkripciós módosulásának meghatározását.

Anyagi támogatás: A munka a „Nemzeti laboratóriumok létrehozása 2020” program keretében készült a Humán Reprodukciós Nemzeti Laboratórium Projekt és az „EFOP-3.6.3-VEKOP-16-2017-00009: Az orvos-, egészségtudományi és gyógyszerészképzés tudományos múhelyeinek fejlesztése” projekt támogatásával.

Szerzői munkamegosztás: B. J., S. E.: A program megtervezése és a kézirat összeállítása. V. Á., K. M.: Adatelemzés és irodalomkutatás. K. L. G.: A kézirat kritikus értékelése és véglegesítése. A cikk végleges változatát valamennyi szerző elolvasta és jóváhagyta.

Érdekeltségek: A szerzőknek nincsenek érdekeltségeik.

\section{Irodalom}

[1] Fülöp V, Vermes G, Demeter J. The relationship between inflammatory and immunological processes during pregnancy. Practical aspects. [A gyulladásos és immunológiai folyamatok kapcsolata a várandósság alatt. Gyakorlati vonatkozások.] Orv Hetil. 2019; 160: 1247-1259. [Hungarian]

[2] Brubel R, Dobó N, Csibi N, et al. The effect of surgical treatment of bowel endometriosis on fertility. [A bélendometriosis miatt végzett mútétek hatása a fertilitásra.] Orv Hetil. 2019; 160: 1633-1638. [Hungarian]

[3] Várnagy A, Bódis J, Kovács GL, et al. Metabolic hormones in follicular fluid in women undergoing in vitro fertilization. J Reprod Med. 2013; 58: 305-311.

[4] Wada K, Hu L, Mores N, et al. Serotonin (5-HT) receptor subtypes mediate specific modes of 5-HT-induced signaling and regulation of neurosecretion in gonadotropin-releasing hormone neurons. Mol Endocrinol. 2006; 20: 125-135.
[5] Bódis J, Török A, Tinneberg HR, et al. Serotonin induces progesterone release from human granulosa cells in a superfused granulosa cell system. Arch Gynecol Obstet. 1993; 253: 59-64.

[6] Il'ková G, Rehák P, Veselá J, et al. Serotonin localization and its functional significance during mouse preimplantation embryo development. Zygote 2004; 12: 205-213.

[7] Veselá J, Rehák P, Mihalik J, et al. Expression of serotonin receptors in mouse oocytes and preimplantation embryos. Physiol Res. 2003; 52: 223-228.

[8] Bódis J, Sulyok E, Kőszegi T, et al. Serum and follicular fluid levels of serotonin, kisspeptin and brain-derived neurotrophic factor in patients undergoing in vitro fertilization: an observational study. Neurohormones in patients receiving IVF. J Int Med Res. 2020; 48(4) Doi: 10.1177/0300060519879330. [Epub 2019 Dec 23]

[9] Kawamura K, Kawamura N, Mulders SM, et al. Ovarian brainderived neurotrophic factor (BDNF) promotes the development of oocytes into preimplantation embryos. Proc Natl Acad Sci USA 2005; 102: 9206-9211.

[10] Feng B, Chen S, Shelden RM, et al. Effect of gonadotropins on brain-derived neurotrophic factor secretion by human follicular cumulus cells. Fertil Steril. 2003; 80: 658-659.

[11] Zhao P, Qiao J, Huang S, et al. Gonadotrophin-induced paracrine regulation of human oocyte maturation by BDNF and GDNF secreted by granulosa cells. Hum Reprod. 2011; 26: 695-702.

[12] Ramer I, Kanninen TT, Sisti G, et al. The serum brain-derived neurotrophic factor concentration prior to initiation of an in vitro fertilization cycle predicts outcome. J Reprod Immunol. 2016; 116: 46-49.

[13] de Roux N, Genin E, Carel JC, et al. Hypogonadotropic hypogonadism due to loss of function of the KiSS1-derived peptide receptor GPR54. Proc Natl Acad Sci USA 2003; 100: 1097210976.

[14] Bhattacharya M, Babwah AV. Kisspeptin: beyond the brain. Endocrinology 2015; 156: 1218-1227.

[15] Dorfman MD, Garcia-Rudaz C, Alderman Z, et al. Loss of Ntrk2/Kisslr signaling in oocytes causes premature ovarian failure. Endocrinology 2014; 155: 3098-3111.

[16] Abbara A, Jayasena CN, Christopoulos G, et al. Efficacy of kisspeptin-54 to trigger oocyte maturation in women at high risk of ovarian hyperstimulation syndrome (OHSS) during in vitro fertilization (IVF) therapy. J Clin Endocrinol Metab. 2015; 100: 3322-3331.

[17] Badaway AA. Tryptophan metabolism, disposition and utilization in pregnancy. Biosci Rep. 2015; 35: e00261.

[18] Munn DH, Zhou M, Attwood JT, et al. Prevention of allogeneic fetal rejection by tryptophan catabolism. Science 1998; 281: 1191-1193.

[19] Groebner AE, Schulke K, Schefold JC, et al. Immunological mechanisms to establish embryo tolerance in early bovine pregnancy. Reprod Fertil Dev. 2011; 23: 619-632.

[20] Christen S, Peterhans E, Stocker R. Antioxidant activities of some tryptophan metabolites: possible implication for inflammatory diseases. Proc Natl Acad Sci USA 1990; 87: 2506-2510.

[21] Weiss G, Diez-Ruiz A, Murr C, et al. Tryptophan metabolites as scavengers of reactive oxygen and chlorine species. Pteridines 2002; 13: 140-145.

[22] Bódis J, Sulyok E, Koppán M, et al. Tryptophan catabolism to serotonin and kynurenine in women undergoing in vitro fertilization. Physiol Res. 2020; 69: 1113-1124.

[23] Agarwal A, Gupta S, Sekhon L, et al. Redox considerations in female reproductive function and assisted reproduction: from molecular mechanisms to health implications. Antioxid Redox Signaling 2008; 10: 1375-1403.

[24] Attaran M, Pasqualotto E, Falcone T, et al. The effect of follicular fluid reactive oxygen species on the outcome of in vitro fertilization. Int J Fertil Womens Med. 2000; 45: 314-320. 
[25] Gardner DK, Wale PL. Analysis of metabolism to select viable human embryos for transfer. Fertil Steril. 2013; 99: 1062-1072.

[26] Seino T, Saito H, Kaneko T, et al. Eight-hydroxy-2'-deoxyguanosine in granulosa cells is correlated with the quality of oocytes and embryos in an in vitro fertilization-embryo transfer program. Fertil Steril. 2002; 77: 1184-1190.

[27] Tamura H, Takasaki A, Miwa I, et al. Oxidative stress impairs oocyte quality and melatonin protects oocytes from free radical damage and improves fertilization rate. J Pineal Res. 2008; 44: 280-287.

[28] Várnagy Á, Kőszegi T, Györgyi E, et al. Levels of total antioxidant capacity and 8-hydroxy-2'-deoxyguanosine of serum and follicular fluid in women undergoing in vitro fertilization: focusing on endometriosis. Human Fertil. 2020; 23: 200-208.

[29] Finkel T, Deng CX, Mostoslavsky R. Recent progress in the biology and phyisiology of sirtuins. Nature 2009; 460: 587-591.

[30] Zhang J, Fang L, Lu Z, et al. Are sirtuins markers of ovarian aging? Gene 2016; 575: 680-686.

[31] Bordone L, Cohen D, Robinson A, et al. SIRTl transgenic mice show phenotypes resembling calorie restriction. Aging Cell 2007; 6: 759-767.
[32] Zhao HC, Ding T, Ren Y, et al. Role of Sirt3 in mitochondrial biogenesis and developmental competence of human in vitro matured oocytes. Hum Reprod. 2016; 31: 607-622.

[33] Palacios JA, Herranz D, De Bonis MI, et al. SIRTl contributes to telomere maintenance and augments global homologous recombination. J Cell 2010; 191: 1299-1313.

[34] Liu M, Yin Y, Ye X, et al. Resveratrol protects against age-associated infertility in mice. Hum Reprod. 2013; 28: 707-717.

[35] Bódis J, Sulyok E, Köszegi T, et al. Serum and follucular fluid levels of sirtuin 1 , sirtuin 6 , and resveratrol in women undergoing in vitro fertilization: an observational, clinical study. J Int Med Res. 2019; 47: 772-782.

(Sulyok Endre dr., Pécs, Vörösmarty u. 4., 7621 e-mail: esulyok@t-online.hu)

\section{"Ab ovo." (Horatius) \\ (A tojástól. - A kezdettől.)}

A cikk a Creative Commons Attribution 4.0 International License (https://creativecommons.org/licenses/by/4.0/) feltételei szerint publikált Open Access közlemény, melynek szellemében a cikk bármilyen médiumban szabadon felhasználható, megosztható és újraközölhetö, feltéve, hogy az eredeti szerzỏ és a közlés helye, illetve a CC License linkje és az esetlegesen végrehajtott módosítások feltüntetésre kerülnek. (SID_1) 